\title{
The value of urban trails, statuary and installations for Geoscience Education: uses and abuses from the north of England and further afield
}

\author{
Phillip J. Murphy ${ }^{1}$, Elizabeth Murphy ${ }^{2}$ \\ 1: School of Earth and Environment, University of Leeds, LS29JT, UK. E-mall: P.J.murphy@leeds.ac.uk \\ 2: 9 Kelghley Road, Colne, Lancashire, BB80LP, UK. E-mall: elizabethmurphy@hotmall.co.uK
}

Abstract Abstract: The origins, uses and fates of a number of purpose built urban educational resources sited in the north of England are reviewed. These include walk on geological maps, building stone trails, a church gate and landscaping in a city park. A geological trail in the municipal cemetery of Rochdale dating from 1855 is a candidate for the oldest purpose made geological education trail in the world and the most recent educational resource was built in 2015. The destruction of a walk on geological map of England and Wales in 2004 shows that such valuable geoscience educational resources are in need of protection. A range of educational uses of these resources are suggested. Comparison is made with similar resources in London, both statuary and web based, and ways to ensure their preservation and continued educational use are suggested. This study shows that a geoscience education resource, if sited in the right place and looked after, can be an exciting and inspirational education resource in regular use for over half a century.

\begin{abstract}
Manuscrito:
Received: Quadrennial Conference of the International Geoscience Education Organization

Accepted: 24/06/2018

Citation: Murphy P.J., Murphy E. 2018. The Value of Urban Trails, statuary and installations for Geoscience Education: uses and abuses from the north of England and further afield. Terræ Didatica, 14(3):277-281. URL: http://www.ige.unicamp.br/terraedidatica/.

Keywords: geology, education, trail, urban, installation Thematic line: Teaching of Geosciences and Natural Sciences for school level education and teacher training
\end{abstract}

\section{Introduction}

The use of urban geology - whether the materials have been transported intentionally for Geoscience education or as part of urban generation and regeneration - provides many opportunities for geological observation and recording without the need for time consuming and costly travel. This is particularly true in the modern age of globalisation where building stone is transported around the world. Another very important aspect of urban geology as an educational resource is that of accessibility. When designing our curricula we need to ensure inclusion for all our students. Urban geology can be a very useful tool in providing a valid geological materials education for those unable for whatever reason to participate in more traditional geoscience fieldwork (e.g. Randles 2017).

A variety of educational opportunities beyond basic observational and descriptive activities are possible, e.g. the quantification of weathering using gravestones is a way to get students measuring process rates as the date of the first exposure to weathering is usually given as part of any inscription. This forms the basis of the Earth Learning Activity "Will my grave stone last?" [1]. A range of activities and educational ideas using grave stone geology are also given by Hannibal (2007). Urban geology studies can be easily differentiated for ability and age, for example as part of a primary (age 5-11) science workshop (e.g. Kennet 2017); secondary (age 11-16) science (e.g. Murphy \& Murphy 2001) as well as part of the University of Leeds undergraduate provision (Murphy \& Evans 2014).

\section{Case studies}

\subsection{Rochdale}

The use of building stones for education is not a new idea in the UK [2]. The first building stone 


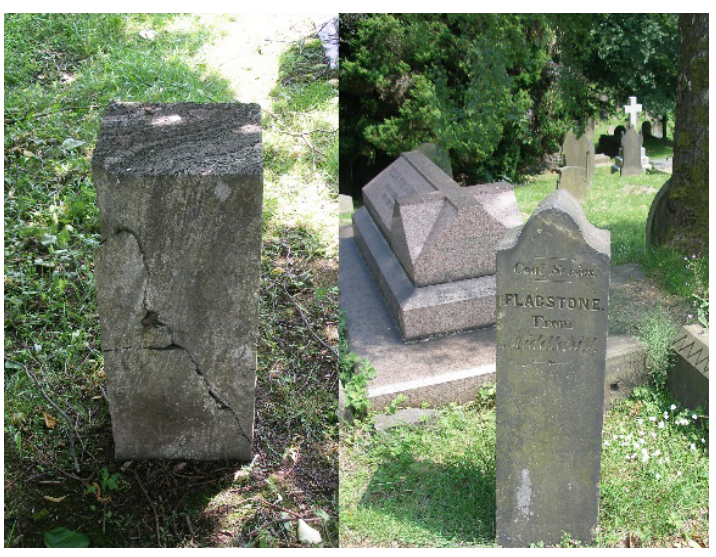

Figure 1. Pillars from the Rochdale geology trail

trail guide for the city of Leeds was published over 75 years ago (Versey 1940) and Manchester over 45 years ago (Simpson \& Broadhurst 1975) though more recent works have been published for both cities (Dimes \& Mitchell 1996, 2006 and Simpson \& Broadhurst 2014). The history of deliberately created geological trails and installations however is much longer with the oldest in the region being in Rochdale Municipal Cemetery, dating from 1855. This is believed to be the work of two local geologists James Horsfall and Robert Law FGS who assisted the architect Abraham Stansfield. 30 stone pillars represent the stratigraphic column as known at the time (Baldwin \&Alderson 1996, Kabrna 2007 p 1\&2). There are start and finish stones bearing scriptural quotations and the pillars are along edges of the access road in the central portion of the cemetery. Each pillar is engraved as to its stratigraphic unit name and geographical origin.

Today a few are missing and the carbonates in particular are badly weathered [3]. Some are leaning in rather precarious positions and the first six specimens are no longer in order but the majority of the original trail can still be followed. The samples are biased towards Victorian resources and building stones, local Carboniferous examples dominate, reflecting the practical origins of our science but there are also samples from Scotland, Wales, Ireland and Italy. This is possibly the oldest purpose built geological education trail in the world. Rochdale cemetery also contains the graves of 15 of the original 28 Rochdale Equitable Pioneers Society - the founders of the cooperative movement. It is due to the principles and success of this society in providing pure food at equitable prices that Rochdale is known as the birthplace of the modern world wide cooperative movement. A trail visiting the graves of these social pioneers is also available [4].

\subsection{Bradford}

The city of Bradford is renowned for its wealth of Victorian architecture including its parks. One such is Lister Park, laid out between 1870 and 1904, which is still very heavily used today and was voted Britain's best park in $2006[5,6]$. The park contains a superb example of Stigmaria, the rooting structure of a Carboniferous coal forest lycopsid tree excavated nearby in 1889 .

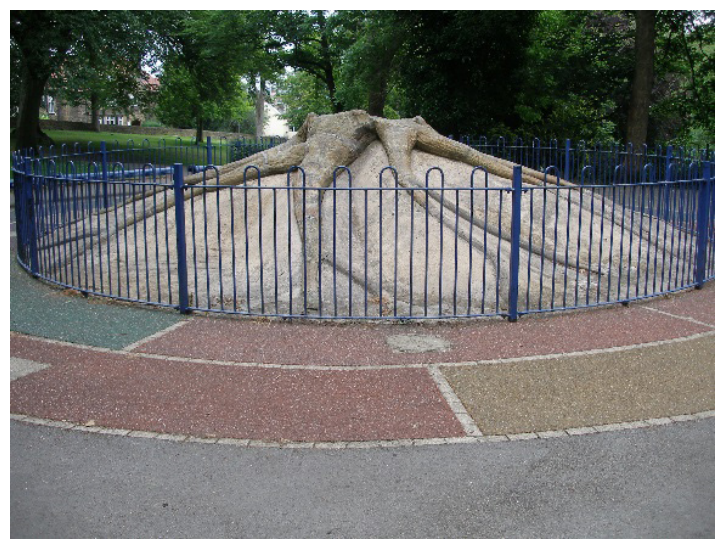

Figure 2. Stigmari in Lister park, Bradford

Less well known is the bigger geological education resource forming part of the botanical gardens in the park. Here limestone and sandstone blocks were laid in way to imitate natural outcrops and covered with soil appropriate plantings. Part of a small stream was diverted to create a waterfall which is a replica of Thornton Force, a well-known waterfall in the nearby Yorkshire Dales National Park, where a classic angular unconformity is exposed $[7,8]$.

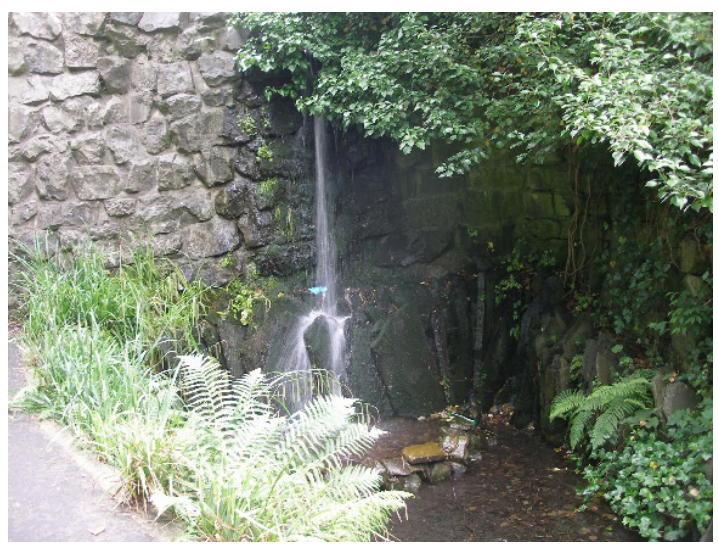

Figure 3. The replica of Thornton Force in Lister Park

While not well publicised the area is well maintained and has recently received new interpretation signage.

\begin{tabular}{c|c|c|c|c|c}
\hline (C) Terrae Didat. & Campinas, SP & v.14 & n.3 & $277-281$ & jul./set. 2018 \\
\hline
\end{tabular}




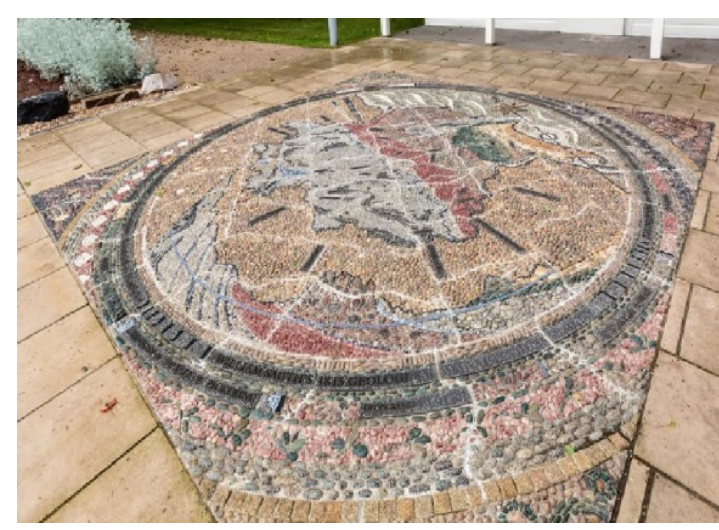

Figure 4. The William Smith mosaic in York museum gardens

\subsection{York}

A recent development has been the creation of a walk-on geological map installation of the county of Yorkshire in the historic city of York. This was commissioned in 2015 by the Yorkshire Philosophical Society and the York Museums Trust in order to celebrate the bicentennial of William Smith's pioneering geological map of England, Wales and southern Scotland (Winchester 2001). This impressive $4 \mathrm{~m} \mathrm{x} 4 \mathrm{~m}$ mosaic art work by artist Janette Ireland used geological materials to demonstrate many of the important points illustrated by Smith.

The materials used in the mosaic reflect the original colours Smith used for his mappable units. Examples of each rock type, along with the materials used to represent them in the construction of the mosaic, are displayed on the edges of the installation. Details of the map including explanatory leaflets can be found at [9]. This shows that geological installations are still considered to be of educational and artistic value today.

\subsection{Leeds}

Unfortunately not everyone appreciates the educational value of urban geology, for example a walk on geological map of England and Wales created in 1957 in the city of Leeds was removed around 2004. The curator of Leeds museums between 1947 and 1957 was Dr. David Owen, a geologist trained at Kings College London. He reinvigorated the geological collections including turning the vaulted cellars beneath the museum building into a replica coal mine (Brears 1989 p22). When the medieval (1152-1538) Cistercian monastic remains of Kirkstall Abbey came under the care of the museums service in 1954 he realised that the park land surrounding the abbey offered opportunities for geological education. An area of lawn near the river was raised up as a sloping terrace and an outline map of England and Wales was cut out and filled with concrete. Blocks of stone sourced from quarries were then erected tombstone-like in appropriate locations on the map with simple two word labels being carved into the blocks - e.g. "Granite, Shap".

Other geological specimens were also added including a sandstone slab showing a Chirotherium footprint and a fossil tree (Brears 1989 p25). The installation, called the Geological Garden, was opened by Professor Henry Cherry Versey of the University of Leeds in 1957. Sadly the garden fell into disrepair through the 1990s though is still fondly remembered by Leeds residents who visited the site as children. By 2001 the site had been vandalised and a number of slabs were broken or missing. The installation was removed sometime around 2004, should you visit the site today it is grassland though the vague outline of the raised terrace can just be discerned. It is a great shame that such an innovative educational resource developed by two of the great geological educators of the city of Leeds, Dr. Owen and Professor Versey, should have been allowed to quietly disappear.

An intriguing surviving example of a geological installation in the Leeds area is the war memorial lychgate at St Marys Church, Whitkirk, in what is now a suburb of the city. A lychgate is a roofed gateway to a churchyard and was traditionally used during the middle ages to shelter corpses until the arrival of the clergyman.

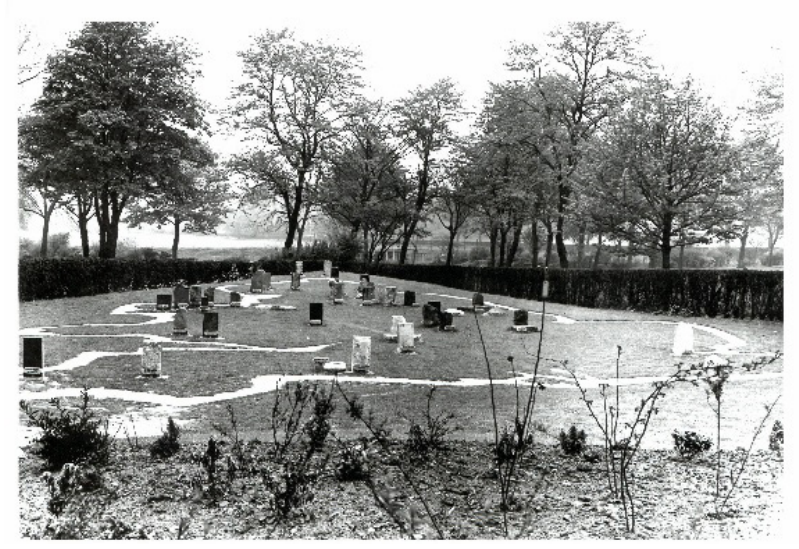

Figure 6. Undated image of the now lost Leeds Geological Garden. By kind permission of Leeds Library and Information Service. www.leodis.net 


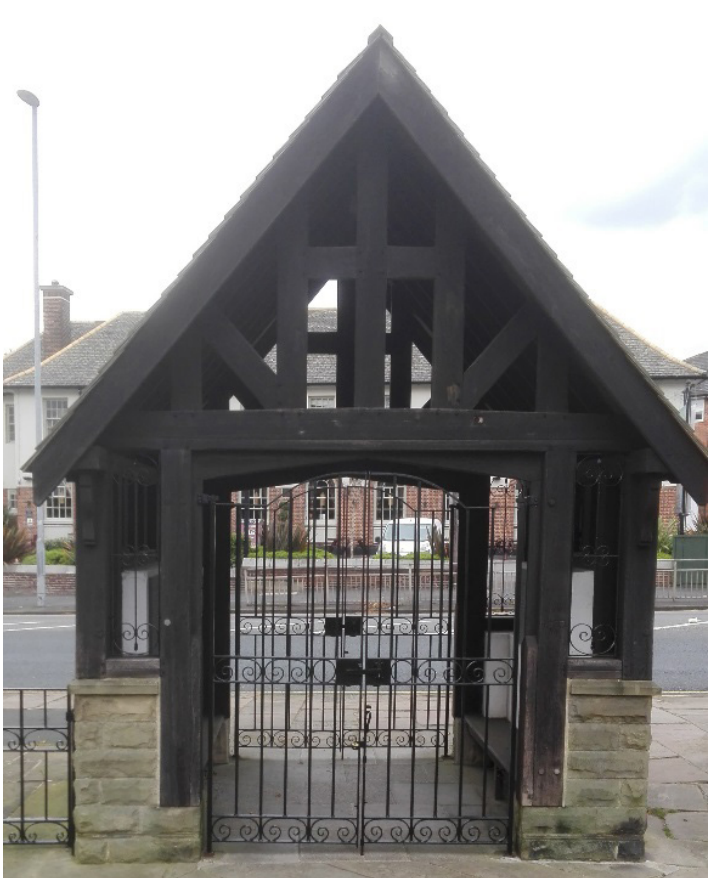

Figure 7. The Lychgate at St Marys Whitkirk

This relatively modern (1949) example contains two panels made of a variety of building stones sourced from buildings damaged by bombing in the Second World War, including the Houses of Parliament and both St Pauls and Coventry cathedrals.

Stone is the traditional material for war memorial construction in the UK but is usually all from one source. This is an unusual and perhaps unique memorial (Murray 2002).

\section{Practical considerations}

If we want to avoid a similar fate befalling other educational resources as has befallen the Leeds geological garden we need to ensure they are used as part of our teaching and as a community of geoscientists we need to be proactive about ensuring they are maintained. One way to avoid loss and damage is to site installations in areas protected from further development such as graveyards (e.g. Rochdale) and religious buildings (e.g. St Mary's, Whitkirk).

The main risk to urban geology trails is the rapid rate of urban renewal, vigilance is needed and regular updates should be produced to avoid information becoming obsolete and trails no longer functioning. This can be a time consuming and costly process but one way to manage this is to give undergraduate students a task to evaluate, update or suggest improvements to an existing resource in order to enhance their own learning. Involving students in trail creation has also proved very successful leading to co-creation of education resources and building a sense of ownership of their education within the student cohort (e.g. Murphy \& Evans 2014) and can be extended to co-delivery and co-responsibility. Urban trail development has also provided opportunities for work based learning (e.g. Burek \& Hope2006).

A move away from printed media to digital platforms is another way to make keeping such teaching resources up to date a more realistic proposal. However, trails designed for mobile digital platforms are in practice often printed as hard copy, not just by older cohorts who often prefer leaflets as an information source (Burek \& Hope 2006) but even by users from the digital native generations. Attempts using QR codes and other markers have resulted $n$ the removal of unlicensed street furniture as well as loss to vandalism. Experience shows that frustration due to hardware and software malfunction/compatibility or urban change results in rapid user disillusionment and disengagement whereas the installations of our Victorian forefathers have stood the test of time and are still used today.

One of the most successful digital platforms for urban geology is that of London Pavement Geology [10], a citizen science style project where data is available on a simple website and everyone can contribute and ensure updates are added. This has evolved at least in part from two books on London's urban geology by Eric Robinson which are classics of the genre (Robinson 1984, 1985) and have inspired many trails and leaflets in the capital and elsewhere (e.g. [11]).

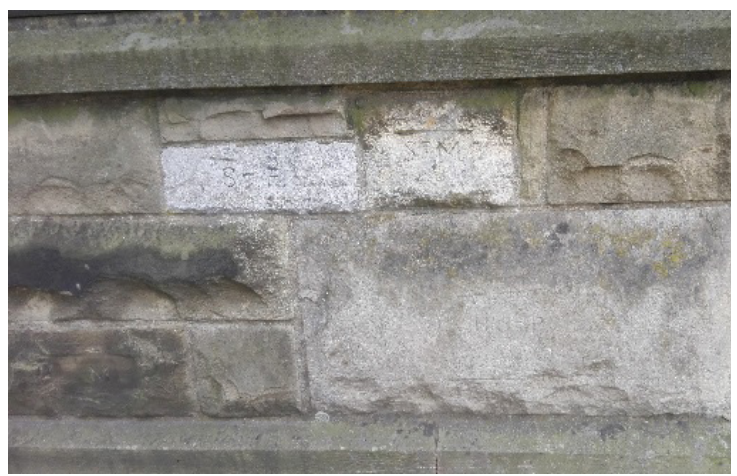

Figure 8. One of the stone panels. $\mathrm{H}$ of P- Houses of Parliament. St.P - St Pauls, London. S'M - St Martins le Grand, York, M - Leeds City Museum 
The first known attempt to model dinosaurs at full scale was undertaken at Crystal Palace in south London. These statues were set in a model geological landscape and the site was opened as a commercial amusement in 1854 one year before the Rochdale cemetery trail. The majority of these models survive and the area was extensively restored in 2002 [12]. It is a very popular educational outing for school and is run and maintained by the park owners (Bromley Borough Council) but is overseen by a charitable body called Friends of Crystal Palace Dinosaurs [13] whose purpose is to promote the long-term conservation of the statues and the larger site. These examples from London may show us the way forward in preserving and using the geological education resources in the north of England.

\section{Conclusions}

Perhaps the approach of London Pavement Geology should be a model for future trail developments in other cities. Urban geology provides a wide range of opportunities for geoscience education and in times of increasing financial pressure offers an inclusive way of ensuring both the general public and geology students see a wide range of rock types. The value of a good geological installation in the right setting cannot be overstated and the Friends of Crystal Palace provides a model of how community involvement and oversight can ensure installations are preserved, maintained and utilised. The long history of urban geology in the UK shows that a geology education resource, if sited in the right place and looked after can be an exciting and inspirational educational resource in regular use for over a century and a half.

\section{References}

Baldwin A., Anderson D.M. 1996. A remarkable survivor: a nineteenth century geological trail in Rochdale, England. The Geological Curator, 6:227-232.

Brears P. 1989. Of curiosities and rare things. The story of Leeds City museum. Friends of Leeds City Museum.

Burek C., Hope M. 2006. The use of town trails in raising awareness of urban geodiversity. International Association for Engineering Geology (IAEG) congress 2006 paper no. 609. Geol. Soc. London. 7pp.

Dimes F.G., Mitchell M. 1996. The building stone heritage of Leeds. The Leeds Philosophical and Literary Society.
Dimes F.G., Mitchell M. 2006. The building stone heritage of Leeds. $2^{\text {nd }}$ ed. The Leeds Philosophical and Literary Society.

Hanibal J.T. 2007. Teaching with tombstones: geology at the cemetery. In: Shaffer N.R., DeChurch D.A. eds. Proceedings of the $40^{\text {th }}$ forum on the geology of industrial minerals, May 2-7, 2004, Bloomington, Indiana: Indiana Geol. Survey Occasional paper, 67:82-88

Kabrna P. 2007. John Milne: the man who mapped the shaking Earth. Craven and Pendle Geological Society

Kennet P. 2017. Primary Matters - fun with geology in primary schools. Teaching Earth Sciences 42(2):55-58

Mitchell M. 2002. The memorial lychgate at St Marys Church, Whitkirk, Leeds. Proceedings of the Yorkshire Geological Society 54(2):121-124

Murphy P.J., Evans R. 2014. Building Stone Trails: a new look at an old friend. Teaching Earth Sciences, 39(2):29-32.

Murphy P.J., Murphy E. 2002. Urban Geological Trails: A tool for teaching key stage three Earth Sciences. School Science Review, 83(305):140-143.

Murphy P J. 2017. A tale (in stone) of four cities. Teaching Earth Sciences, 42(2):38-40.

Randles A. 2017. Rock around Campus. Teaching Earth Sciences, 42(2):53.

Robinson E. 1984. London illustrated geological walks. Scottish Academic Press.

Robinson E. 1985. London illustrated geological walks book 2. Scottish Acad. Press.

Simpson I., Broadhurst F. 1975. A Building Stones Guide to Central Manchester. Dept. Extra Mural Studies, Univ. Manchester.

Simpson M. \& Broadhusrt F.A. (Revised: Strother P., Rhodes J). 2014. A building stones guide to Central Manchester (third edition). Manchester Geol. Assoc.

Versey H C. 1940. Ornamental stones of Leeds. Trans. Leeds Geol. Assoc., 5(5):297-300.

Winchester S. 2001. The map that changed the world. Penguin Books.

[1] http://www.earthlearningidea.com/PDF/135_ Gravestones.pdf

[2] http://www.englishstone.org.uk/Biblio_c.html

[3] http://rochdale-past.co.uk/geological-stone-pillars/

[4] http://www.rochdale.gov.uk/pdf/463\%20-\%20Pioneers\%20graves\%20booklet.pdf

[5]https:/www.bradford.gov.uk/media/2272/manningham09listerpark.pdf

[6]https://historicengland.org.uk/listing/the-list/ list-entry/1001222

[7] http://www.cpgs.org.uk/

[8] http://www.ingletonwaterfallstrail.co.uk/

[9] https://www.yorkmuseumgardens.org.uk/the-mosaic-map/

[10] http://londonpavementgeology.co.uk/

[11] http://www.ucl.ac.uk/ ucfbrxs/Homepage/UrbanGeology.htm

[12] https://www.visitlondon.com/things-to-do/ place/198408-crystal-palace-park\# rilHgOYODpCg541s.97

[13] http://cpdinosaurs.org/ 